\title{
An Investigation of Elementary School Teachers' Sense of Number
}

\author{
Zübeyde ER, Perihan DINÇ ARTUT \\ Çukurova University, Adana, Turkey
}

\begin{abstract}
This research primarily investigates elementary school teachers' sense of number. This is a descriptive research with a survey model. The participants of the study were 155 primary school teachers teaching in state schools in Adana, in the South of Turkey. As a data collection tool, a test of sense of number was used. This test was composed of 50 items, prepared according to the five components of sense of number. The data was analysed through quantitative methods. The results show that the elementary school teachers' sense of number is at the mid-level. In line with the findings of the study, suggestions are given to develop primary school teachers' sense of number.
\end{abstract}

Keywords: sense of number, primary school teachers, mathematics education

\section{Introduction}

A qualified teacher should be equipped with strong subject knowledge and pedagogic domain knowledge. Pedagogic domain knowledge implies teaching approaches used to make a concept or a topic more comprehensible for others; whereas, subject knowledge is the amount and organization of knowledge in a teacher's mind (Shulman, 1986).

Even (1990) claimed that a teacher with strong mathematics knowledge can help his students get meaningful learnings. He added that subject knowledge is an important component in teacher training. This component has a significant place in understanding, planning, and teaching mathematics.

Sense of number is vital in terms of the subject knowledge types that a teacher should have, so it is needed to explain the position and importance of this concept in mathematics. One of the best ways of achieving this is to focus on the skills of a student with a good sense of number. Making mathematical operaions, a student with a good sense of number can find out his own methods, can express a number in a way that fits into the situation and can make transitions between quantities in the real world and the numbers in the world of mathematics (Case, 1998, as cited in Şengül \& Dede, 2014). While busy with operations in their mind, students with sense of number can make planning and control, can be flexible and can decide if the results are reasonable or not (Mohamed \& Johnny, 2010). In short, a student equipped with a good sense of number can use daily life and school mathematics in a flexible way and in a way that makes his/her life easy.

It is possible for students to acquire sense of number through mathematics courses. In line with this, teachers responsible for giving these courses should put forward their skills which are related to this concept.

\footnotetext{
Zübeyde ER, math teacher, Department of Elementary School Education, Faculty of Education, Çukurova University.

Perihan DİNÇ ARTUT, assoçiate professor, Department of Elementary School Education, Faculty of Education, Çukurova University.
} 
Teachers can contribute into the acquisition of this concept by means of the classroom atmosphere they organize, teaching methods they use, and activities they implement (Tsao \& Lin, 2011), so teachers' schemata about sense of number are important.

\section{Literature Review}

In a general perspective, sense of number means making logical calculations about various uses, realizing mathematical faults and number patterns and making decision on the most effective calculation way (Hope, 1989, as cited in Altay, 2010). According to Altay (2010), sense of number is defined as:

Using numbers flexibly, practical thinking in operations with numbers, choosing the most effective and practical solution, in some situations creating non-standard ways that do not go in line with the situation, using comparison (reference) point in facilitating problems, and using conceptual thinking and different ways of showing in fractions.

As sense of number is a difficult concept to define, it has caused controversies among mathematical trainers (teachers, programme developers, and researchers) and cognitive psychologists (McIntosh, Reys, \& Reys, 1992). These arguments have also been observed in revealing the components of sense of number.

In their study on the classifications of sense of number components, Şengül and Dede (2013), mentioned that there was no common classification regarding the components of sense of number in the related literature. They concluded that the most comprehensive classification was done by McIntosh et al. (1992). They thought that it derived from the fact that there were no certain borders of the concept of sense of number.

Following the classification by McIntosh et al. (1992), Sighn (2009) grouped the components of sense of number as understanding number concept, using multiple representations, understanding the effect of the operation, using equivalent presentations and calculation, and using counting strategies. In this present research, the components that Sighn (2009) formulated were used. In line with the explanations in the related literature, these components were considered as in the following manner:

\section{Understanding Number Concepts}

This component is about understanding the value that the number represented and the size that the number indicated. They understand and use the numbers and relationships completely (Harç, 2010). For example, the skill of knowing that there are indefinite decimal number between 0.5 and 0.6 is a sign of this component.

\section{Using Multiple Representations}

This is related to knowing different representations of the number or the value the number represented. For example, finding the number which best represents a dredged area in a whole is a sign of this component.

\section{Understanding the Effect of Operations}

This is related to realise how the result can be affected when a number or the value of the operation is changed in an operation. In short, a person who is capable of understanding the effect of the operation can know how four operations can affect the numbers (Yang, Reys, \& Reys, 2009). In other words, it means to know that the multiplication does not always make the numbers higher and the division does not always make the numbers lower (Graeber \& Tirosh, 1990; Greer, 1987; McIntosh et al., 1992). For example, realising that when 30 is multiplied by 0.09 , the result will be lower than 30 is a sign of this component.

\section{Using Equivalent Expression}

This is related to knowing the numbers in different expressions, that is, their equivalences. For example, 
understanding that two out of five can also be represented by an equivalence or understanding that $70 \times 0.5$ and 70:2 are equivalent symbolize this component (İymen, 2012).

\section{Using Counting and Computation Strategies}

This is related to knowing the result of the operation without using pen and pencil. In the related literature, it has been seen that there are studies about sense of number with elementary school students (Altay, 2010; Altay \& Umay, 2011; Aunio, Lim, Hautamaki, \& Van Luit, 2004; İymen, 2012; Markovits \& Pang, 2007; Markovits \& Sowder, 1994; Pike \& Forrester, 1997; Reys, Kim, \& Bay, 1999; Sengul \& Gulbagci, 2012; Zaslavsky, 2001) and with teacher candidates (Altay \& Umay, 2011; Clarke, 2012; Şengül, 2013; Şengül \& Dede, 2014; Yaman, 2014; Yaman, 2015; Yang, 2007; Yang, Reys, \& Reys, 2009). No studies have been found with elementary school teachers

These examples given above reveal that strong content knowledge is a must for an effective mathematics education. Also, it has been thought that it is important to investigate the teachers' skills related to sense of number as it is one of the skills that elementary school students should be equipped with. In addition, following the idea that sense of number can be developed (Olkun, 2012; Şengül \& Dede, 2014; Tsao, 2012), it has been aimed to investigate whether teachers' experience with numbers during their teaching career is influential on the development of their sense of number. Considering all these explanations, it has been thought that this study contributes into the related literature and it is possible to make recommendations for the training of elementary school teachers. The research questions of the study are as below:

1. Is there a difference in elementary school teachers' sense of number performances in terms of gender?

2. How is elementary school teachers' sense of number performances?

3. Is there a difference in elementary school teachers' sense of number performances in terms of teaching experience period?

4. What is elementary school teachers' performances about the components of sense of humor in terms of teaching experience period?

5. Is there a difference in elementary school teachers' performances about the components of sense of number in terms of teaching experience period?

\section{Method}

This is a descriptive research with a survey model, investigating elementary school teachers' sense of number.

\section{Participants}

The participants of the study were chosen through convenience sampling. One hundred and fifty-five elementary school teachers working in state schools in Adana, a city in the South of Turkey participated in the study. Table 1 gives information about the participants' gender and teaching experience period.

As seen in Table 1, ouf ot 155 elementary school teachers, 97 of them are female and 58 of them are male. It has been seen that nearly $13.5 \%$ of the participants have the teaching experience period of $1-5,16.1 \%$ of them have been teaching for 6-10 year, $18.7 \%$ of them have been teaching for 11-15 year, $38.7 \%$ have been teaching for $16-20$ year, and $12.9 \%$ of them have been teaching for 21 year and more. 
Table 1

Elementary School Teachers in Terms of Teaching Experience Period and Gender

\begin{tabular}{lllllll}
\hline Gender & $1-5$ year & $6-10$ year & $11-15$ year & $16-20$ year & $21-25$ year & Total \\
\hline Female & 13 & 21 & 18 & 36 & 9 & $97(62.6 \%)$ \\
Male & 8 & 4 & 11 & 24 & 11 & $58(34.4 \%)$ \\
Total & $21(13.5 \%)$ & $25(16.1 \%)$ & $29(18.7 \%)$ & $60(38.7 \%)$ & $20(12.9 \%)$ & 155 \\
\hline
\end{tabular}

Data Collection Tool

As a data collection tool, the test of sense of number (SNT) adapted by Sing (2009) by following McIntosh, Reys, Reys, Bana, and Farrell (1997) was translated into Turkish by the researchers. The translated form was presented to three English language teachers and two mathematics teachers, specialized in teaching mathematics. The form was revised in line with feedback received. Then, the test was administered to piloted with three elementary school teachers in order to see whether the SNT items were clear enough or not. The reliability coefficient was found as 0.812 .

In the SNT test, there are five components with 50 items. They are understanding the number concept, using the multiple representations, understanding the effect of the operation, using equivalences and calculations, and using counting strategies. Table 2 shows the components of the SNT test and the distribution of the questions in line with these components.

Table 2

Components of the Sense of Number Test and the Disribution of These Questions in Line With the Components and Sample Items

\begin{tabular}{|c|c|c|}
\hline Components & Items & Example item \\
\hline $\begin{array}{l}\text { Understanding } \\
\text { number concepts }\end{array}$ & $\begin{array}{l}\text { Number of items: } 14 \\
\text { Item no: } 1,3,4,6,9,10,15,18 \\
19,22,25,29,36,39\end{array}$ & $\begin{array}{l}\text { Item 3: How many different decimal are there between } 1.52 \text { and } 1.53 ? \\
\text { Circle your answer and then fill in the blank. } \\
\text { A. None. Why? } \\
\text { B. One. What is it? } \\
\text { C. A few. Give two examples. } \\
\text { D. Many. Give two examples. } \\
\end{array}$ \\
\hline $\begin{array}{l}\text { Using multiple } \\
\text { representations }\end{array}$ & $\begin{array}{l}\text { Number of items: } 7 \\
\text { Item no: } 7,8,13,14,30,31,40\end{array}$ & Item 8: \\
\hline & & $\begin{array}{l}\text { Circle the decimal which best represents the amount of the box shaded. } \\
\begin{array}{lllll}\text { (A) } 0.018 & \text { (B) } 0.15 & \text { (C) } 0.4 & \text { (D) } 0.801 & \text { (E) } 0.52\end{array}\end{array}$ \\
\hline $\begin{array}{l}\text { Understanding the } \\
\text { effect of the } \\
\text { operation }\end{array}$ & $\begin{array}{l}\text { Number of items: } 10 \\
\text { Item no: } 16,17,20,21,24,27 \\
28,38,48,49\end{array}$ & $\begin{array}{l}\text { Item 16: } \\
\text { Without calculating the exact answer, circle the best estimate for: } 9 \text { x } 0.98 \\
\begin{array}{ll}\text { A. More than } 9 \quad \text { B. Less than } 9 \\
\text { C. Impossible to tell without working it out }\end{array}\end{array}$ \\
\hline $\begin{array}{l}\text { Using equivalent } \\
\text { expression }\end{array}$ & $\begin{array}{l}\text { Number of items: } 8 \\
\text { Item no: } 11,23,26,32,33 \\
34,37,45\end{array}$ & $\begin{array}{l}\text { Item } 11: \\
0.5 \times 840 \text { is the same as: } \\
\begin{array}{lll}\text { A. } 840 \div 2 & \text { B. } 840+2 & \\
\text { C. } 5 \times 8400 \text { E. } 0.50 \times 84 & \text { D. } 5 \times 840\end{array}\end{array}$ \\
\hline $\begin{array}{l}\text { Using calculation } \\
\text { and counting } \\
\text { strategies }\end{array}$ & $\begin{array}{l}\text { Number of items: } 11 \\
\text { Item no: } 2,5,12,35,41,42,43 \text {, } \\
44,46,47,50\end{array}$ & $\begin{array}{l}\text { Item 2: } \\
\text { Ten bottles of orange juice cost a total of Turkish Lira (TL) } 7.95 \text { at K } \\
\text { shop. I can get } 5 \text { bottles of the same juice for a total of TL } 4.15 \text { at L shop. } \\
\text { Where is a bottle of orange juice cheaper? } \\
\text { A. At K shop B. At L shop } \\
\text { Tell how you decided: }\end{array}$ \\
\hline Total & 50 items & \\
\hline
\end{tabular}




\section{Data Collection}

The SNT test was administered to the teachers individually. They were instructed to leave 30-45 seconds to each item in the test, so they were guided to make use of their sense of number but not calculating.

\section{Data Analysis}

Before the data was analysed, all items in the test were checked if they were answered in line with the instructios and if there were any items left unaswered.

The data analysis was done through the Statistical Package for the Social Sciences (SPPS) 15.0 programme. Following the aim of the research, the frequency analysis $(f)$, the percentage $(\%)$, and the mean $(X)$ were calculated regarding the components of sense of number. The correct answers were evaluated as "1" and incorrect answers " 0 ." The independent $t$-test was computed in order to test the significance of the participants' SNT scores regarding gender. Next, one-way ANOVA was computed to see if there were significant differences in the participants' sense of number test scores for irrelevant measures with respect to teaching experience period. Also, MANOVA was used to test if the participants' scores in the test differed significantly regarding sense of number test.

\section{Findings}

In this section, the findings were given and they were interpreted in line with the research questions.

\section{Findings and Interpretations of the Elementary School Teachers' Sense of Number Scores in Terms of Gender}

The indepedendent groups $t$-test was used to test the significance of the elementary school teachers' SNT scores regarding gender. The results were given in Table 3 .

Table 3

Elementary School Teachers' $t$-Test Results Based on the Test of Sense of Number in Terms of Gender

\begin{tabular}{lllllll}
\hline Gender & $N$ & $\bar{x}$ & $S S$ & $S d$ & $t$ & $P$ \\
\hline Female & 97 & 36.22 & 6.64 & & & 0.69 \\
Male & 58 & 38.01 & 4.36 & 153 & 1.82 & \\
Total & 155 & & & & & \\
\hline
\end{tabular}

As seen in Table 3, the mean of the female participants' sense of number test scores was 36.22 and that of male participants was 38.01. Also, the standard deviation of the male participants has found to be higher than that of female participants. It implied that the male teachers had a more homogen structure; whereas, the female teachers were heterogenous. Independent groups $t$-test was computed to see if the differences was significant or not in terms of gender and no significant difference was found $(t(153)=1.82 p>0.01)$.

\section{Findings Related to the Elementary School Teachers' Sense of Number Performances Regarding Teaching Experience Period}

Table 4 points out the mean and the standard deviation of the elementary school teachers' sense of number performances in terms of teaching experience period.

According to Table 4, the teachers with 11-15 teaching experience period had the highest mean (37.96) and the teachers with the teaching experience of 21 year had the lowest mean (34.90). Keeping in mind that the highest score to be taken from the SNT was 50 , it was possible to say that the elementary school teachers' sense 
of number performances was low. Referring to all information given above, then, one-way ANOVA was computed to see if there was a significant difference in the elementary school teachers' sense of number test for irrelevant sampling regarding teaching experience period. Table 5 illustrates the ANOVA results.

Table 4

Elementary School Teachers' Sense of Number Performances Regarding Teaching Experience Period

\begin{tabular}{lll}
\hline Teaching experience & $\bar{x}$ (Max. 50) & $S S$ \\
\hline $1-5$ year & 36.33 & 7.65 \\
$6-10$ year & 37.64 & 5.00 \\
$11-15$ year & 37.96 & 5.82 \\
$16-20$ year & 36.93 & 5.04 \\
21 and more & 34.90 & 7.53 \\
Mean & 36.89 & 5.94 \\
\hline
\end{tabular}

Tablo 5

ANOVA Results of Elementary School Teachers' Sense of Number Test Scores Regarding Teaching Experience Period

\begin{tabular}{lcrlll}
\hline Source of variation & The sum of squares & \multicolumn{1}{c}{$S d$} & The mean of squares & $F$ & $P$ \\
\hline Between group & 133.423 & 4 & 33.356 & & \\
Within group & $5,304.926$ & 150 & 35.366 & 0.943 & 0.441 \\
Total & $5,438.348$ & 154 & & & \\
\hline
\end{tabular}

No significant difference was observed in the elementary school teachers' sense of number test scores with respect to their teaching experience period $(F(4,150)=0.943, p>0.01)$.

Findings and Interpretations Related to the Elementary School Teachers' Components of the Sense of Number in Terms of Teaching Experience Period

Findings and interpretations about understanding the concept of number compoent. Table 6 points out the frequency of correct answers regarding this component.

Table 6

Elementary School Teacher' Percentage Distribution Related to the Component of Understanding the Number Concept in Terms of Teaching Experience Period

\begin{tabular}{lllllll}
\hline Item no & $1-5$ year & $6-10$ year & $11-15$ year & $16-20$ year & $21-25$ year & Mean \\
\hline 1 & 90.5 & 88.0 & 89.7 & 86.7 & 90.0 & 88.4 \\
3 & 66.7 & 60.0 & 69.0 & 55.0 & 60.0 & 60.6 \\
4 & 95.2 & 100. & 100 & 98.3 & 85.0 & 96.0 \\
6 & 71.4 & 56.0 & 62.1 & 48.3 & 40.0 & 54.2 \\
9 & 61.9 & 40.0 & 20.7 & 46.7 & 40.0 & 41.9 \\
10 & 90.5 & 92.0 & 89.7 & 85.0 & 75.0 & 86.5 \\
15 & 85.7 & 76.0 & 93.1 & 83.3 & 80.0 & 83.9 \\
18 & 47.6 & 64.0 & 69.0 & 61.7 & 50.0 & 60.0 \\
19 & 47.6 & 60.0 & 58.6 & 48.3 & 30.0 & 49.7 \\
22 & 76.2 & 80 & 89.7 & 88.3 & 85.0 & 85.2 \\
25 & 90.5 & 80.0 & 79.8 & 83.3 & 80.0 & 81.9 \\
29 & 85.7 & 92.0 & 79.3 & 78.3 & 90.0 & 83.2 \\
36 & 85.7 & 96.0 & 93.1 & 80.0 & 80.0 & 85.8 \\
39 & 38.1 & 52.0 & 31.0 & 35.0 & 55.0 & 40.0 \\
Mean & 73.80 & 62.85 & 73.2 & 69.87 & 67.14 & 71.23 \\
\hline
\end{tabular}


According to Table 6, the percentage mean of the correct answer of the elementary school teachers' understanding of the concept of number component was $71.23 \%$. The highest score belonged to the teachers with 1-2 teaching experience period as seen in Table 6. It was seen that the teachers with the teaching experience of 6-10 year had the lowest score. Regarding all teaching experience period category, the lowest score was observed in the 9th item (41.9\%) and in the 39th item (40\%). In the 39th item, it was expected that the integer part consisted of a number with four digits and the comma would be in the appropriate place. However, the research findings showed that the teachers did not realise this point.

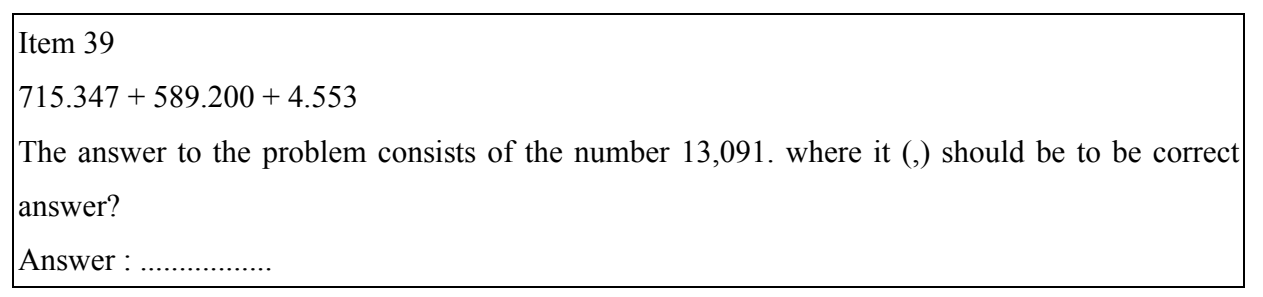

Findings related to the component of using multiple representations. Table 7 illustrates the percentage distribution of the correct answers related to the component of using multiple representations.

Table 7

The Percentage Distribution of the Component of Using Multiple Representations Regarding the Teachers' Teaching Experience Period

\begin{tabular}{lllllll}
\hline Item no & $1-5$ year & $6-10$ year & $11-15$ year & $16-20$ year & $21-25$ year & Mean \\
\hline 7 & 85.7 & 76.0 & 93.1 & 88.3 & 65.0 & 83.9 \\
8 & 76.2 & 68.0 & 89.7 & 76.7 & 75 & 77.4 \\
13 & 28.6 & 44.0 & 48.3 & 40.0 & 35.0 & 40.0 \\
14 & 28.6 & 32.0 & 41.4 & 28.3 & 30.0 & 31.6 \\
30 & 76.2 & 84.0 & 89.7 & 86.7 & 90.0 & 85.8 \\
31 & 76.2 & 88.0 & 79.3 & 86.7 & 80.0 & 83.2 \\
40 & 81.0 & 80.0 & 86.2 & 85.0 & 90.0 & 84.5 \\
Mean & 64.64 & 67.42 & 75.38 & 70.24 & 66.42 & 69.48 \\
\hline
\end{tabular}

As seen in Table 7, the percentage of correct answers of the elementary school teachers' using multiple representations was $69.48 \%$. The highest percentage belonged the the participants with 11-15 year of teaching experience and the lowest percentage belonged to the participants with 21-25 year of teaching experience. Regarding all teaching experience periods, the lowest achievement was observed in the 14th item (31.6\%) and 13 th item $(40.0 \%)$. It was seen that the elementary school teachers had difficulty in finding the value that the number represented on the number line and in expressing the number in a fraction where the numerator was nearly twice the denominator.

Item 14

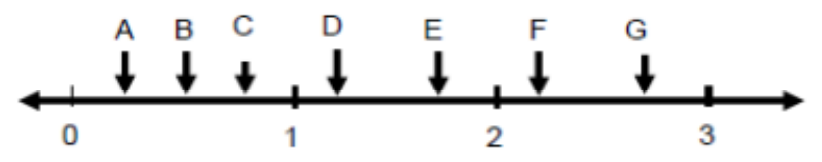

Which letter in the number line above shows a fraction where the numerator is nearly twice the denominator?

Answer: 
Findings and interpretations about the component of understanding the effect of operation. This component is related to the abiliy of realising how the results changes when a number or the value of the operation changes in calculations. Table 8 illustrates the the percentage distribution of correct answers that the elementary teachers give to this component.

Table 8

The Frequency Distribution of the Elementary School Teachers' Correct Answers About Understanding the Effect of the Operation in Terms of Teaching Experience Period

\begin{tabular}{lllllll}
\hline Item no & $1-5$ year & $6-10$ year & $11-15$ year & $16-20$ year & $21-25$ year & Mean \\
\hline 16 & 85.7 & 96.0 & 96.6 & 93.3 & 75.0 & 91.0 \\
17 & 76.2 & 92.0 & 96.6 & 93.3 & 75.0 & 89.0 \\
20 & 9.50 & 8.00 & 17.2 & 15.0 & 10.0 & 12.9 \\
21 & 61.9 & 68.0 & 62.1 & 68.3 & 50.0 & 63.9 \\
24 & 23.8 & 24.0 & 17.2 & 21.7 & 35.0 & 23.2 \\
27 & 71.4 & 72.0 & 86.2 & 76.7 & 75.0 & 76.8 \\
28 & 81.0 & 84.0 & 89.7 & 71.7 & 65.0 & 77.4 \\
38 & 95.2 & 100 & 100 & 98.3 & 90.0 & 97.4 \\
48 & 85.7 & 88.0 & 96.6 & 91.7 & 95.0 & 91.6 \\
49 & 71.4 & 72.0 & 72.4 & 83.3 & 60.0 & 74.8 \\
Mean & 66.18 & 70.4 & 73.46 & 71.33 & 63.0 & 69.8 \\
\hline
\end{tabular}

According to Table 8, it was seen that the mean of correct answers about the component of understanding the effect of the operation was $69.8 \%$. The highest score was observed with the teachers who had 11-15 teaching experience period and the lowest score belonged to the teachers with 21-25 year of teachnig experience. With respect to all teaching experience periods, the lowest score was seen in the 20th item (12.9\%).

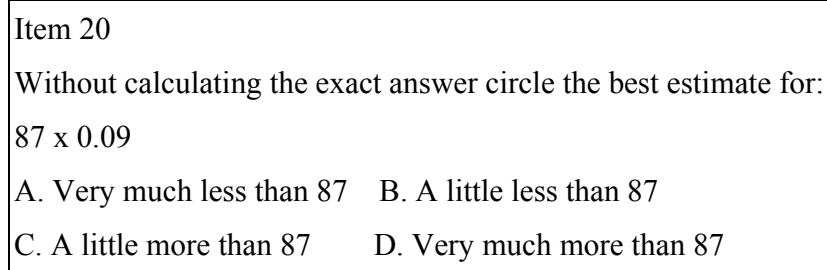

When the 20th item was considered, it was seen that some elementary school teachers who gave incorrect answer perceived the operation as a multiplication of two numbers. They thought that the answer would be more than 87 and chose the wornd answer. It was thought that they did not consider that the value of the multiplication decreased as one of the numbers was a decimal number.

Findings and interpretations about the component of using equivalences. In using equivalences, the elementary school teachers were expected to find the equivalence of the results of the operation and to use the appropriate symbol, such as equal sign, greater or lesser signs. The percentage distribution of correct answers the elementary school teacher give is shown in Table 9.

According to Table 9, the percentage mean of correct answer about using the equivalences is $79.2 \%$. The elementary school teachers with the teaching experience of 11-12 year had the highest achievement percentage and the teachers with the teaching experience of 21-25 year had the lowest achievement percentage. Regarding all teaching experience periods, the lowest achievement was observed in the 23th item (49\%). 
Table 9

The Percentage Distribution of the Correct Answers of the Elementary School Teachers' Using Equivalences in Terms of Teaching Experience Period

\begin{tabular}{lllllll}
\hline Item no & $1-5$ year & $6-10$ year & $11-15$ year & $16-20$ year & $21-25$ year & Mean \\
\hline 11 & 81.0 & 88.0 & 89.7 & 88.3 & 85.0 & 87.1 \\
23 & 42.9 & 60.0 & 55.2 & 45.0 & 45.0 & 49.0 \\
26 & 66.7 & 84.0 & 75.9 & 81.7 & 55.0 & 75.5 \\
32 & 100 & 92.0 & 96.6 & 91.7 & 95.0 & 94.2 \\
33 & 61.9 & 72.0 & 72.4 & 48.3 & 45.0 & 58.1 \\
34 & 71.4 & 76.0 & 86.2 & 75.0 & 70.0 & 76.1 \\
37 & 100 & 96 & 100 & 95.0 & 95.0 & 96.8 \\
45 & 100 & 100 & 96.6 & 96.7 & 90.0 & 96.8 \\
Mean & 77.98 & 83.5 & 84.07 & 77.71 & 72.5 & 79.2 \\
\hline
\end{tabular}

\begin{tabular}{l} 
Item 23 \\
Write "is greater than," "is equal to," or " is less than" to make this a true statement: \\
$\qquad 5 \times 7 \frac{1}{2} \ldots \ldots .35 \div \frac{1}{2}$ \\
\hline
\end{tabular}

In this item, the teachers were expected to use the symbol of " $<$ ". But, the teachers thought that the results was equal and they used the symbol of "=", instead of "<".

Findings and interpretations about the component of calculating and using counting strategies. Table 10 shows the percentage distribution of correct asnwers about the component of the elementary school teachers' use of calculating and counting strategies.

Table 10

The Percentage Distribution of Correct Answers Given to Using Calculation and Counting Strategies by the Elementary School Teachers in Terms of Teaching Experience Period

\begin{tabular}{lllllll}
\hline Item no & $1-5$ year & $6-10$ year & $11-15$ year & $16-20$ year & $21-25$ year & Mean \\
\hline 2 & 85.7 & 96.0 & 89.7 & 96.7 & 90.0 & 92.9 \\
5 & 76.2 & 80.0 & 79.3 & 73.3 & 85.0 & 77.4 \\
12 & 76.2 & 76.0 & 75.9 & 85.0 & 65.0 & 78.1 \\
35 & 81.0 & 92.0 & 69.0 & 86.7 & 70.0 & 81.3 \\
41 & 90.5 & 96.0 & 96.6 & 93.3 & 100 & 94.8 \\
42 & 95.2 & 92.0 & 96.6 & 93.3 & 100 & 94.8 \\
43 & 4.80 & 4.00 & 3.40 & 10.0 & 15.0 & 7.7 \\
44 & 90.5 & 84.0 & 93.1 & 78.3 & 95.0 & 85.8 \\
46 & 90.5 & 96.0 & 96.6 & 90.0 & 100 & 93.5 \\
47 & 81.0 & 72.0 & 55.2 & 86.7 & 75.0 & 76.1 \\
50 & 90.5 & 96.0 & 86.2 & 95.0 & 80.0 & 91.0 \\
Mean & 78.3 & 80.36 & 67.72 & 80.75 & 79.54 & 79.4 \\
\hline
\end{tabular}

According to Table 10, the mean of correct answers about using calculating and counting strategies by the elementary school teachers is $\mathbf{7 9 . 4 \%}$. For this component, the highest achievement score belonged to the teachers with the teaching experience period of 6-10 year; whereas, the lowest score was by the elementary school teachers with the teaching experience period of 11-15 year. With respect to all teaching experience periods, the lowest achievement was observed in the 43th item (7.7\%). 
Then, MANOVA was calculated to see whether the SNT sense of number components score significantly changed regarding teaching experience period. Table 11 points out he MANOVA results. It was seen that the sense of number components had no effect on teachers' experience period (Wilks Lambda $(\Lambda)=0.795$, $F(1.734)=, p>0.01)$.

Table 11

The SNT Components Mean, Standard Deviations and One-Way Variance Analysis Results in Terms of Teaching Experience Peripd

\begin{tabular}{|c|c|c|c|c|c|c|}
\hline $\begin{array}{l}\text { Components of } \\
\text { sense of number }\end{array}$ & $\begin{array}{l}\text { Teaching } \\
\text { experience }\end{array}$ & $\bar{x}$ & $S S$ & $S d$ & $F$ & $P$ \\
\hline \multirow{6}{*}{$\begin{array}{l}\text { Understanding } \\
\text { the concept of } \\
\text { number }\end{array}$} & $1-5$ & 10.33 & 2.61 & \multirow{6}{*}{$4-150$} & \multirow{6}{*}{0.901} & \multirow{6}{*}{0.465} \\
\hline & $6-10$ & 10.36 & 1.62 & & & \\
\hline & $11-15$ & 10.20 & 2.09 & & & \\
\hline & $16-20$ & 9.78 & 1.96 & & & \\
\hline & $21-25$ & 9.40 & 2.77 & & & \\
\hline & Total & 9.98 & 2.15 & & & \\
\hline \multirow{6}{*}{$\begin{array}{l}\text { Using multiple } \\
\text { Representations }\end{array}$} & $1-5$ & 4.52 & 1.74 & \multirow{6}{*}{$4-150$} & \multirow{6}{*}{0.924} & \multirow{6}{*}{0.452} \\
\hline & $6-10$ & 4.72 & 1.67 & & & \\
\hline & $11-15$ & 5.27 & 1.19 & & & \\
\hline & $16-20$ & 4.91 & 1.44 & & & \\
\hline & $21-25$ & 4.65 & 1.95 & & & \\
\hline & Total & 4.86 & 1.55 & & & \\
\hline \multirow{6}{*}{$\begin{array}{l}\text { Understanding } \\
\text { the effect of the } \\
\text { operation }\end{array}$} & $1-5$ & 6.61 & 1.46 & \multirow{6}{*}{$4-150$} & \multirow{6}{*}{2.565} & \multirow{6}{*}{0.41} \\
\hline & $6-10$ & 7.04 & 1.27 & & & \\
\hline & $11-15$ & 7.34 & 1.26 & & & \\
\hline & $16-20$ & 7.13 & 1.19 & & & \\
\hline & $21-25$ & 6.30 & 1.49 & & & \\
\hline & Total & 6.98 & 1.32 & & & \\
\hline \multirow{6}{*}{$\begin{array}{l}\text { Using } \\
\text { equivalences }\end{array}$} & $1-5-$ & 6.23 & 1.37 & \multirow{6}{*}{$4-150$} & \multirow{6}{*}{2.186} & \multirow{6}{*}{0.73} \\
\hline & $6-10$ & 6.68 & 1.14 & & & \\
\hline & $11-15$ & 6.72 & 1.25 & & & \\
\hline & $16-20$ & 6.21 & 1.30 & & & \\
\hline & $21-25$ & 5.80 & 1.23 & & & \\
\hline & Total & 6.33 & 1.29 & & & \\
\hline \multirow{6}{*}{$\begin{array}{l}\text { Calculating } \\
\text { aplama } \\
\text { and using sayma } \\
\text { stra } \\
\text { counting } \\
\text { strategies }\end{array}$} & $1-5$ & 8.61 & 1.93 & \multirow{6}{*}{$4-150$} & \multirow{6}{*}{0.492} & \multirow{6}{*}{0.741} \\
\hline & $6-10$ & 8.84 & 1.31 & & & \\
\hline & $11-15$ & 8.41 & 1.63 & & & \\
\hline & $16-20$ & 8.88 & 1.43 & & & \\
\hline & $21-25$ & 8.75 & 1.74 & & & \\
\hline & Total & 8.73 & 1.56 & & & \\
\hline
\end{tabular}

\section{Discussion, Result, and Suggestions}

Investigating elementary school teachers' sense of number skills, this study was based on the data collected with 155 elementary school teachers.

In this study, the sense of number was analysed in terms of gender and teaching experience period. It was seen that the elementary school teachers' sense of number performances were low and this profile did not change with regard to gender and teaching experience period. Also, the sense of number component on which 
the elementary school teachers gave the most correct answers were calculating and using counting strategies. The percentage of correct answers in this component was $79.4 \%$ and the percentage mean of correct answers in the component of using equivalences was $79.2 \%$.

In their study, Altay and Umar (2011) investigated the elementary school teachers' calculating skills and the relationship between this and sense of number regarding grades. They found out that the elementary school teachers' sense of number was low. Similarly, Yang (2007) carried out a study focusing on elementary school candidate teachers' strategies use in the sense of number problems. Yang concluded that most of the elementary school candidae teachers preferred written calculation ways in solving problems. According to Yang (2007), this results was an evidence of teacher candidates' low performance of sense of number skills. In addition to this, Yang, Reys, and Reys (2009) did a study on Taiwanese elementary school candidate teachers' use of strategies in solving the real life problems. In their study, they found that the teacher candidates mostly used rule-based strategies. They added that this derived from the fact that their sense of number was low. Yaman (2014) also presented similar findings from her study focusing on the elementary school candidate teachers' sense of number skills with respect to grade, so the results of this present research can be said to be compatible with the findings in the related literature (Altay \& Umay, 2011; Yang, 2007; Yang, Reys, \& Reys, 2009; Yaman, 2014).

In different studies with a focus on the sense of number at the level of elementary school. Parallel findings were observed (Harç, 2010; Altay, 2010; Şengül \& Gülbağc1, 2012). Considering both the studies in Turkey and abroad, it was seen that the skill of sense of number was not high with both students and teachers. Şengün (2013) claimed that this profile is a good support and example in Turkey for a perspective proposed by Alam and Reys (2007), and Reys, Kim, and Bay (1999) in the related literature. Alamı and Reys (2007), and Reys et al. (1999) said that the children and teachers in the countries shared the same problems.

This study showed that teaching experience period had no effect on the sense of number performances. In liene with this, Yaman (2014) presented parallel findings to this study, emphasizing the low sense of number skills at teacher candidates.

All in all, it was concluded that the elementary school teachers' sense of number performances were found to be low and this was not changed regarding gender and teaching experience period. Moreover, it was found that the sense of number component that the the most correct answers were observed was calculating and use of of counting strategies.

As a suggestion, it can be proposed that the teacher should be trained in a way that they realize the importance of sense of number. Also, elementary school teachers should be aware of their students' sense of number and they should attend training programmes about how they can improve their students' sense of number skills and what kind of activities can be implemented and what kind of lesson plans should be prepared for this. Furthermore, training should be given to elementary school teachers to develop their mental calculation skills and prediction skills, so students' sense of number are developed.

\section{References}

Altay, M. K. (2010). An investigation of middle grade students number sense in terms of grade level, gender and components of number sense (Doctoral thesis, Hacettepe University, Social Sciences Institute, Ankara, Turkey).

Altay, M. K., \& Umay, A. (2013). The development of number sense scale towards middle grade students. Egitim ve Bilim, $38(167), 241-255$. 
Altay, M. K., \& Umay, A. (2011). An investigation of the relationship between calculation ability and number sense of prospective elementary teachers. e-Journal of New World Sciences Academy, 6(1), 1277-1283.

Alajmi, A., \& Reys, R. (2007). Reasonable and reasonableness of answers: Kuwaiti middle school teachers' perspectives. Educational Studies in Mathematics, 65(5), 77-94.

Aunio, P., Ee, J., Lim, S. E. A., Hautamaki, J., \& ve Van Luit, J. E. H. (2004). Young children's number sense in Finland, Hong Kong and Singapore. International Journal of Early Years Education, 12(3), 195-216.

Courtney-Clarke, M. A. E. (2012). Exploring the number sense of final year primary preservice teachers (Master's thesis, Stellenbosch University, Stellenbosch).

Even, R. (1990). Subject matter knowledge for teaching and the case of functions. Educational Studies in Mathematics, 21, 521-554.

Graeber, A. O., \& Tirosh, D. (1990). Insights fourth and fifth grades bring to multiplication and division with decimals. Educational Studies in Mathematics, 21, 565-588.

Greer, B. (1987). Nonconservation of multiplication and division involving decimals. Journal for Research in Mathematics Education, 18, 37-45.

Harç, S. (2010). Analysis of the current situation of the 6th grade students in term ofnumber sense concept (Mater's thesis, Marmara University, İstanbul).

İymen, E. (2012). Analysis of 8th grade students' number sense related to the exponents interms of sense components (Mater's thesis, Pamukkale University, Denizli).

K1lıç, Ç. (2011). Number sense in the elementary mathematics curriculum (1-5) and NCTM principles. In 1st International Conference on Curriculum and Instruction, IEskişehir.

Markovits, Z., \& Pang, J. (2007, July). The ability of 6th grade students in Korea and Israel to cope with number sense tasks. In Proceedings of the 31st Conference of the International Group for the Psychology of Mathematics Education (Vol.3, pp. 241-248).

Markovits, Z., \& Sowder, J. (1994). Developing number sense: An intervention study in Grade 7. Journal for Research in Mathematics Education, 25, 4-29.

McIntosh, A., Reys, B. J., \& Reys, R. E. (1992). A proposed framework for examining basic number sense. For the Learning of Mathematics, 12(3), 2-8.

McIntosh, A., Reys, B. J., Reys, R. E., Bana, J., \& Farrel, B. (1997). Number sense in school mathematics: Student performance in four countries. Mathematics Science and Technology Education Centre, Edith Cowan University.

Milli Eğitim Bakanlığı (MEB). (2011). Elementary school mathematics curriculum and instruction manual (1-5 grades). Ankara: Milli Eğitim Basımevi.

Mohamed, M., \& ve Johnny, J. (2010). Investigating number sense among students. Procedia Social and Behavioral Sciences, 8 , 317-324.

Olkun, S. (2012). What is the number sense? Why is it important? How is to improve? Ankara Üniversty, Faculty of Educational Sciences. Retrieved September 19, 2015, from http://www.vitaminogretmen.com/dokumanlar/6606

Pike, C. D., \& Forrester, M. A. (1997). The influence of number sense on children's ability to estimate measures. Educational Psychology, 17(4), 483-500.

Reys, B. J., Kim, O. K., \& ve Bay, J. M. (1999). Establishing fraction benchmarks. Mathematics Teaching in the Middle School, 4(8), 530-532.

Singh, P. (2009). An assessment of number sense among secondary school students. International Journal for Mathematics Teaching and Learning. Retrieved from http://www.cimt.plymouth.ac.uk/journal/singh.pdf

Sengul, S., \& Gulbagci, H. (2012). An investigation of 5th grade Turkish students' performance in number sense on the topic of decimal numbers. Procedia-Social and and Behavioral Sciences, 46, 2289-2293.

Şengül, S. (2013). Identification of number sense strategies used by pre-service elementary teachers. Educational Sciences: Theory \& Practice, 13(3), 1965-1974.

Şengül, S., \& Dede, H. G. (2014). The strategies of mathematics teachers when solving number sense problems. Turkish Journal of Computer and Mathematics Education (TURCOMAT), 5(1), 73-88.

Şengül, S., \& Dede, H. G. (2013). An investigation of classification of number sense components. International Journal of Social Science, 6(8), 645-664.

Shulman, S. L. (1986). Those who understand: Knowledge growth in teaching. Educational Researcher, 15(2), 4-14.

Tsao, Y. L. (2012). Number sense of pre-service teachers. Research in Higher Education Journal, 16, 1. 
Tsao, Y. L., \& Lin, Y. C. (2011). The study of number sense and teaching practice. Journal of Case Studies in Education, 2(1), $1-14$.

Yaman, H. (2014). Number sense performances of preservice teachers. Grade Level, 23(2), 739-754.

Yang, D. C. (2007). Investigating the strategies used by pre-service teachers in Taiwan when responding to number sense questions. School Science and Mathematics, 107(7), 293-301.

Yang, D. C., Reys, R. E., \& ve Reys, B. J. (2009). Number sense strategies used by preservice teachers in Taiwan. International Journal of Science and Mathematics Education, 7, 383-403.

Zaslavsky, C. (2001). Developing number sense: What can other cultures tell us? Teaching Children Mathematics, 7(6), $312-319$. 